\title{
Polisi dan Realiti Gaji Minimum di Negeri Sabah: Satu Kajian Kes Pekerja Kontrak Pembersihan di Universiti Malaysia Sabah The Policy and Reality of Minimum Wage in Sabah: A Case Study of Contract Janitors in UMS
}

\author{
${ }^{1}$ MOHD KHAIRUL NABIL BIN MOHD NOR AZAN \\ ${ }^{2}$ DZURIZAH IBRAHIM
}
Fakulti Kemanusiaan, Seni dan Warisan, Universiti Malaysia Sabah, Jalan UMS 88400 Kota Kinabalu.
Imohdkhairulnabil169@yahoo.com
idzuri@ums.edu.my

\begin{abstract}
Abstrak Pelaksanaan gaji minimum di Malaysia pada dasarnya bermula apabila Akta Majlis Perundingan Gaji Negara (Akta 732) dikuatkuasakan mulai 15 September 2011. Bersandarkan kepada Pelaksanaan Perintah Gaji Minimum 2012 (Sabah, Sarawak dan Labuan) yang telah diperkenalkan pada September 2012, Sabah memulakan operasi agar para majikan di Sabah turut melaksanakan gaji minimum kepada para pekerja masingmasing. Penguatkuasaan pelaksanaan gaji minimum di Malaysia pada 1 Januari 2014 meletakkan gaji minimum di Semenanjung Malaysia sebanyak RM900, manakala Sabah dan Sarawak sebanyak RM800. Gaji minimum diperkenalkan bertujuan menjaga hak dan kebajikan pekerja menerusi 'fair pay' bagi membantu golongan pekerja sekali gus menggalakkan mobiliti. Namun, sejauh mana alasan-alasan tersebut dan kesedaran tentang kewujudan gaji minimum diketahui oleh para pekerja masih menjadi persoalan, khususnya dalam konteks pekerja di negeri Sabah. Artikel ini membincangkan tahap kesedaran pekerja terhadap gaji minimum serta menilai sejauh mana pembayaran gaji minimum dilaksanakan dalam sektor pembersihan di Universiti Malaysia Sabah (UMS) menerusi temu bual mendalam ke atas dua orang wakil pengurusan dan 16 orang responden dalam kalangan pekerja pembersihan. Kajian mendapati bahawa tahap kesedaran pekerja terhadap kewujudan dan pelaksanaan gaji minimum adalah sifar. Walaupun majikan mengakui telah melaksanakan gaji minimum, dapatan kajian menemukan sebaliknya. Manipulasi maklumat oleh majikan telah mengekang pelaksanaan gaji minimum untuk dilaksanakan secara berkesan. Kajian ini penting sebagai sandaran untuk memastikan hak dan kebajikan pekerja bukan sahaja di Sabah tetapi juga di Kepulauan Borneo ini secara amnya dapat dipelihara.
\end{abstract}


Kata kunci: Gaji minimum, polisi, Sabah, pekerja kontrak pembersihan, Universiti Malaysia Sabah (UMS).

Abstract The implementation of a minimum wage in Malaysia basically began when the National Wage Consultative Council Act (Act 732) came into force on 15 September 2011. In accordance with the Minimum Wage Act that was introduced in September 2012, Sabah's employers have started implementing the Minimum Wage Act (2012) on their workers. The implementation of a minimum wage in Malaysia have become mandatory on 1 January 2014, thus a minimum wage of RM900 has been set for workers in Peninsular Malaysia and RM800 for the workers in Sabah and Sarawak. The reason for introducing a minimum wage is protecting workers'rights and welfare through fair pay policy which is intended to help workers and also to encourage worker mobility. However, the awareness of employees about the existence of the minimum wage is still questionable, especially workers in Sabah. Therefore, this paper discussed the level of employee awareness with regard to the minimum wage, as well as assessed the extent of the minimum wage implementation in the cleaning services in Universiti Malaysia Sabah via in-depth interviews with two management representatives of the cleaning service organizations and 16 janitors. This study found that the level of employee awareness of the existence and implementation of the minimum wage was zero. Although employers claimed to implement the minimum wage, the research findings showed otherwise. The manipulation of information by the employers have constrained the effective implementation of the minimum wage. This study is important to ensure the rights and welfare of the employees are preserved, not only in Sabah but also in Borneo.

Keywords: Minimum wage, policy, Sabah, contract janitors, Universiti Malaysia Sabah (UMS). 


\section{PENGENALAN}

Gaji minimum ialah jumlah minimum yang perlu dibayar kepada pekerja ke atas kerja yang telah dilaksanakan atau ke atas perkhidmatan yang diberikan, dalam tempoh masa yang ditetapkan, sama ada dikira pada asas masa atau "output" yang tidak boleh dikurangkan, sama ada secara individu atau perjanjian kolektif, yang dijamin oleh undang-undang dan boleh ditetapkan dalam apa jua cara untuk menampung keperluan minimum pekerja dan keluarganya, dalam apa sahaja keadaan ekonomi negara dan sosial (International Labour Organisation (ILO), 2014). Di Malaysia, maksud gaji minimum di bawah Perintah Gaji Minimum 2012 adalah sama dengan tafsiran gaji minimum di bawah Seksyen 2,Akta Majlis Gaji Negara 2011 (Akta 732), iaitu gaji minimum sebagai gaji pokok.

Malaysia telah melaksanakan Akta Gaji Minimum pada 1 Januari 2013 dan seterusnya pada 1 Januari 2014, akta tersebut telah menjadi satu akta mandatori. Pelaksanaan pembayaran gaji minimum kepada pekerja adalah berbeza mengikut kawasan. Gaji minimum di Semenanjung Malaysia adalah RM900, manakala di Labuan, Sabah dan Sarawak pula, gaji minimum adalah RM800. Walaupun gaji minimum telah menjadi satu akta mandatori untuk dilaksanakan, sejauh mana pelaksanaannya oleh majikan di Sabah masih menjadi tanda tanya. Di samping itu, kesedaran pekerja terhadap pelaksanaan gaji minimum dan seterusnya kesan dari tahap kesedaran pekerja tersebut terhadap pelaksanaan gaji minimum di Sabah juga perlu dikenal pasti.

\section{SOROTAN LITERATUR}

Lazimnya, gaji minimum diperkenalkan di sesebuah negara untuk menjaga hak dan kebajikan pekerja menerusi apa yang dikenali sebagai "fair pay" (Scotland Equal Opportunity Commission, 2003; Lilly Ledbetter Fair Pay Act, 2009). Tujuan tersebut menunjukkan kepentingan fungsi pelaksanaan gaji minimum dilaksanakan yang mana ia berkait rapat dengan hak dan juga kebajikan seseorang pekerja di samping ia diwujudkan untuk membantu golongan yang kurang berkemampuan (Majlis Perundingan Gaji Negara (MPGN), 2012). 
Perkara ini menunjukkan bahawa pelaksanaan gaji minimum di negeri Sabah adalah untuk membantu golongan pekerja yang mana sebelum ini mendapat purata gaji yang jauh lebih rendah daripada kos sara hidup di negeri Sabah, iaitu sebanyak RM577 (Kementerian Sumber Manusia Putrajaya, 2012), manakala kos sara hidup negeri Sabah pula adalah RM1,048 (Lee Heng Guie, 2012). MPGN (2012) turut menyatakan bahawa penciptaan lantai gaji bertujuan supaya tidak ada pekerja yang bekerja di sesuatu kawasan yang menerima gaji di bawah paras lantai gaji yang telah ditetapkan di dalam Akta Gaji Minimum. Namun demikian, Thurab-Nkhosi (2007) menyatakan bahawa pelaksanaan sesuatu polisi baharu pasti mengalami cabaran. Dalam konteks ini, cabaran pelaksanaan gaji minimum dilihat mencakupi faktor-faktor seperti kelayakan akademik pekerja, teknologi yang diguna pakai oleh sesebuah organisasi, pengurusan sesebuah organisasi dan juga disebabkan oleh kewangan sesebuah organisasi (Thurab-Nkhosi, 2007).

Pada dasarnya, pelaksanaan gaji minimum di Malaysia adalah berbeza mengikut kawasan. Di Semenanjung Malaysia, gaji minimum pekerja pada awal pelaksanaannya ditetapkan sebanyak RM900, manakala gaji minimum di Labuan, Sabah dan Sarawak ditetapkan pada kadar RM800 sebulan. Keadaan ini membawa kepada satu persoalan, iaitu adakah pelaksanaan gaji minimum pekerja ini dilaksanakan sepenuhnya oleh pihak majikan di negeri Sabah kerana jumlah pembayaran gaji yang berbeza dan kurang RM100 daripada gaji minimum yang terdapat di Semenanjung Malaysia. Keadaan ini juga membawa kepada persoalan tentang kesan pelaksanaan gaji minimum ini kepada pekerja.

Scotland Equal Opportunity Commission (2003) dan Lilly Ledbetter Fair Pay Act (2009) menyatakan bahawa gaji minimum adalah satu bentuk pembayaran gaji yang adil. Oleh itu, gaji minimum di Malaysia diandaikan sebagai 'gaji yang adil' (fair pay) di mana sebelum pelaksanaan gaji minimum, gaji penengah pekerja adalah dalam anggaran RM577 (Kementerian Sumber Manusia Putrajaya, 2012) dan jumlah tersebut adalah jauh lebih rendah daripada kos sara hidup pekerja iaitu RM1,048 (Lee Heng Guie, 2012). Walaupun masih wujud jurang gaji pekerja, peningkatan tersebut telah mengurangkan jurang perbezaan antara kos sara hidup dan gaji pekerja. 
Sungguhpun gaji minimum dianggap sebagai gaji yang adil, peningkatan pada gaji seseorang pekerja akan menyebabkan pihak pengurusan sesebuah organisasi menurunkan kadar 'pengambilan pekerjaan' (dalam Ambrosi, 1986; Neumark \& Wascher, 2001). Kesan penurunan pengambilan pekerja secara tidak langsung akan memberikan kesan kepada 'beban kerja' yang mana menurut Davies (2013), pengurangan kepada bilangan pekerja akan menyebabkan peningkatan kepada beban kerja dan secara tidak langsung ketiga-tiga elemen iaitu 'gaji adil', 'pengambilan pekerjaan' dan 'beban kerja' mempunyai perkaitan yang jelas. Ringkasnya, gaji pekerja akan mempengaruhi pengambilan pekerja dan beban kerja seorang pekerja. Oleh itu, sejauh mana konsep tersebut benar-benar kesan daripada pelaksanaan gaji minimum merupakan antara persoalan yang wujud dalam kajian ini.

Pelaksanaan gaji minimum juga bertujuan mengelakkan berlakunya mobiliti pekerja dari satu kawasan ke kawasan kerja yang lain (MPGN, 2012). Namun begitu, secara amnya, setiap organisasi wajib memberikan gaji minimum kepada pekerjanya, iaitu sekurang-kurangnya RM800. Hal ini secara tidak langsung mengelakkan pekerja berpindah kawasan kerja jika tidak berpuas hati dengan skop kerja yang dilaksanakan. Heinz dan WardWarmedinger (2006) dan Ezzeddine (2011) menyatakan bahawa antara sebab berlakunya mobiliti pekerja adalah kerana adanya perbezaan gaji, manakala Dieleman dan Harnmeijer (2006) menyatakan bahawa antara sebab berlakunya mobiliti pekerja adalah disebabkan oleh kepuasan pekerjaan yang berkaitan dengan faktor kemudahan kesihatan seperti pertimbangan kewangan, keadaan tempat kerja, keupayaan dan cara pengurusan, kemajuan profesional dan tempat kerja yang selamat. Keadaan ini menunjukkan bahawa pekerja akan mempunyai kecenderungan untuk memilih tempat kerja yang mempunyai kemudahan dan mampu memberikan faedah yang lebih kepada seseorang pekerja. Justeru, gaji minimum berkemungkinan mampu mengelakkan berlakunya mobiliti pekerja dari satu kawasan kepada kawasan kerja yang lain. Namun demikian, sejauh mana ia dapat mengelakkan berlakunya mobiliti pekerja di antara organisasi dalam konteks kajian ini masih perlu dikaji. 


\section{METODOLOGI KAJIAN}

Kajian ini menggunakan pendekatan kajian kes kualitatif, iaitu melalui kaedah temu bual ke atas dua orang wakil pengurusan dan 16 orang responden dalam kalangan pekerja pembersihan dari dua buah syarikat pembersihan yang mendapat kontrak pembersihan di UMS. Pemilihan responden adalah secara rawak mudah dan setiap organisasi diwakili seramai lapan responden. Anggaran masa yang digunakan untuk satu sesi temu bual adalah selama 35 minit bagi setiap seorang responden pekerja kontrak pembersihan. Masa keseluruhan yang digunakan dalam mengutip data temu bual kesemua responden adalah sebanyak 9 jam dan 20 minit. Untuk menjaga kerahsiaan, nama sebenar responden dan organisasi tidak digunakan.

Jadual 1 mengilustrasikan profil responden pekerja di dua organisasi pembersihan yang mendapat kontrak pembersihan di UMS. Jadual 1 tersebut jelas menunjukkan bahawa organisasi pembersihan A mempunyai kecenderungan untuk menggaji pekerja bukan warganegara Malaysia. Hal ini disebabkan tujuh daripada lapan orang responden merupakan pekerja asing, manakala seorang responden sahaja yang menyatakan bahawa beliau adalah pekerja warganegara Malaysia. Keadaan ini jauh sekali berbeza dengan organisasi pembersihan B di mana kecenderungan majikan untuk menggaji pekerja adalah lebih kepada pekerja berstatus warganegara Malaysia kerana kesemua lapan orang responden adalah pekerja warganegara Malaysia. Dari aspek umur, umur responden pekerja yang diambil bekerja bagi kedua-dua sektor pembersihan adalah tidak menentu. Namun, organisasi pembersihan B mempunyai tiga orang pekerja yang berumur lebih daripada 50 tahun, manakala pekerja di organisasi pembersihan A pula tidak mempunyai pekerja yang berumur lebih daripada 50 tahun. 
Jadual 1 Profil responden pekerja pembersihan

\begin{tabular}{|l|c|c|}
\hline & Organisasi A & Organisasi B \\
\hline Jantina & 1 & 1 \\
Lelaki & 7 & 7 \\
Perempuan & 2 & 2 \\
\hline Umur & 3 & 1 \\
$18-20$ tahun & \\
$21-30$ tahun & 2 & 2 \\
$31-40$ tahun & 1 & 3 \\
$41-50$ tahun & - & 8 \\
Lebih 50 tahun & 1 & - \\
\hline Warganegara & 7 & 3 \\
Malaysia & & - \\
Bukan Malaysia & - & 5 \\
\hline Kelayakan akademik & - & - \\
PMR & - & 2 \\
SPM & 8 & 1 \\
UPSR dan ke bawah & & 1 \\
Tiada kelayakan akademik & 6 & 4 \\
\hline Tempoh perkhidmatan & 1 & \\
Kurang setahun & & \\
1 - 2 tahun & 1 & \\
$3-4$ tahun & & \\
Lebih 5 tahun &
\end{tabular}

Kesemua pekerja di organisasi pembersihan A tidak memiliki sebarang kelayakan akademik, manakala di organisasi pembersihan B pula, kesemuanya mempunyai kelayakan akademik sekurang-kurangnya di peringkat sekolah rendah. Perkara ini berkaitan dengan status kewarganegaraan seseorang pekerja. Pekerja di organisasi pembersihan A mempunyai kecenderungan pusing ganti pekerja yang tinggi, adalah kerana seramai enam orang pekerja mempunyai jangka masa bekerja kurang daripada setahun dan masing-masing seorang pekerja sahaja yang bekerja dalam anggaran satu hingga dua tahun dan lebih daripada lima tahun. Keadaan ini berbeza sedikit dari organisasi pembersihan B, iaitu kebanyakan responden (empat orang) telah berkhidmat dalam anggaran lebih daripada lima tahun, manakala selebihnya adalah pekerja yang bekerja pada organisasi tersebut untukjangka masa tiga hingga empat tahun dan jangka masa bekerja satu hingga dua tahun, masing-masing seorang responden dan dua responden yang bekerja kurang daripada setahun. 


\section{DAPATAN KAJIAN}

Walaupun Akta Gaji Minimum telah menjadi akta mandatori yang wajib dilaksanakan berkuat kuasa pada 1 Januari 2014, organisasi pembersihan A masih tidak melaksanakannya. Hasil temu bual mendapati bahawa kesemua lapan orang responden masih menerima gaji di bawah paras gaji minimum, iaitu jika mereka hadir sepenuh masa bekerja, jumlah bersih gaji yang akan dibayar oleh pihak majikan kepada pekerja adalah RM600. Gaji RM600 adalah termasuk bonus kehadiran penuh pekerja, di mana RM560 merupakan gaji pekerja dan RM40 lagi merupakan bonus kehadiran penuh bekerja. Jika seseorang pekerja tidak hadir satu hari bekerja, maka bonus RM40 tidak akan diperoleh dan gaji pekerja akan ditolak RM20 untuk satu hari pekerja tersebut tidak hadir.

Keadaan ini jelas menunjukkan bahawa pekerja bagi organisasi pembersihan A tidak mendapat gaji minimum seperti yang telah dinyatakan oleh pihak majikan mereka dan juga seperti mana yang telah dikuatkuasakan menerusi akta mandatori oleh Kerajaan Malaysia. Berbeza dengan organisasi A, organisasi B pula didapati telah melaksanakan pembayaran gaji minimum kepada kesemua pekerjanya yang telah bekerja sebelum 1 Januari 2014, iaitu seramai enam orang pekerja telah mendapat pembayaran gaji minimum sebanyak RM800. Sementara itu, pekerja yang baru sahaja bekerja, iaitu kurang daripada enam bulan bekerja mendapat gaji kurang daripada RM800 kerana pekerja tersebut masih dianggap dalam tempoh percubaan. Perkara ini jelas dinyatakan oleh pihak MPGN, iaitu pekerja dalam tempoh percubaan akan dibayar sekurang-kurangnya 30 peratus daripada gaji minimum namun perkara tersebut tertakluk kepada kontrak perkhidmatan seseorang pekerja.

Kajian turut mendapati bahawa tahap kesedaran pekerja mengenai gaji minimum adalah sangat rendah. Di organisasi A misalnya, kesemua responden pekerja tidak mengetahui langsung maksud gaji minimum. Bagi organisasi B pula, terdapat lima orang responden yang tidak mengetahui apakah maksud gaji minimum dan hanya tiga orang responden di organisasi B yang mengetahui berkenaan dengan gaji minimum. Walau bagaimanapun, mereka hanya mengetahui bahawa gaji yang diterima oleh mereka adalah 
satu proses peningkatan gaji yang asal kepada RM800. Keadaan ini menunjukkan tahap kesedaran pekerja mengenai pelaksanaan gaji minimum adalah rendah dan menunjukkan bahawa pihak majikan tidak memberikan pendedahan kepada pekerja mengenai pelaksanaan gaji minimum.

Rentetan daripada tahap kesedaran yang rendah mengenai gaji minimum dalam kalangan responden pekerja di organisasi A, pekerja turut menjadi mangsa manipulasi apabila beban kerja pekerja turut bertambah walaupun gaji minimum tidak dibayar oleh majikan. Berikut antara pernyataan pekerja mengenai layanan majikan mereka.

"Saya terbeban dengan tugas sekarang kerana sepatutnya dua orang
perlu bersihkan empat bangunan dalam masa seminggu... kalau dulu
(sebelum pelaksanaan gaji minimum) kami ramai... jadi mudah
melakukan tugas tapi sekarang kerja lebih banyak berbanding dulu..."
(Jonah, tukang sapu yang telah berkhidmat 1 tahun 2 bulan)

"Banyak kerja di sini... semua blok bangunan perlu dibersihkan dalam masa seminggu tapi kami tidak ramai dan saya rasa kerja pembersihan yang saya perlu lakukan cukup membebankan."

(Dayang, tukang sapu yang telah berkhidmat 1 tahun 8 bulan).

"Oleh kerana saya seorang sahaja pekerja lelaki maka majikan selalu menyuruh saya melakukan tugas-tugas yang lebih berat seperti mengangkat sampah-sampah berat dan sebagainya. Saya rasa terbeban."

(Jimmy, tukang sapu yang telah berkhidmat 1 tahun).

Pernyataan responden di organisasi A jelas menunjukkan bahawa mereka terbeban dengan tanggungjawab kerja yang diberikan oleh majikan akibat kekurangan pekerja.

Namun, hal ini tidak pula berlaku di organisasi B kerana beban kerja pekerja tidak meningkat malahan pekerja masih lagi melakukan rutin pembersihan kawasan yang ditugaskan seperti mana sebelum pembayaran gaji minimum dilaksanakan. Hanya tiga orang pekerja sahaja yang merasakan terbeban dengan tugasan kerja yang diberikan oleh majikan organisasi B, di mana dua daripada tiga pekerja tersebut merupakan pekerja baharu dan pernyataan mereka adalah seperti berikut; 
"Saya rasa terbeban dengan tugas saya... sebab saya terpaksa menolong pekerja wanita kerana mereka perlukan bantuan."

(Alan, tukang sapu yang telah berkhidmat 8 bulan).

"Pekerja lain semua dapat RM800, tapi saya hanya dapat paling sedikit RM600...sedangkan tugas saya membebankan."

(Mona, tukang sapu yang telah berkhidmat 4 bulan).

"Kerja saya sama macam yang lain tapi gaji yang saya terima sedikit... lainlah kalau majikan tunaikan janjinya selepas enam bulan dia akan bayar gaji yang sama."

(Jannie, tukang sapu yang telah berkhidmat 4 bulan).

Pernyataan tersebut jelas menunjukkan bahawa ada responden yang meragui majikan mereka dalam meningkatkan gaji kepada RM800, manakala seorang lagi responden merasa terbeban kerana perlu membantu pekerja wanita apabila diperlukan.

Dari aspek kadar beban kerja dan jumlah gaji yang diterima, empat orang responden di organisasi A menyatakan mereka berpuas hati, tiga orang pula tidak berpuas hati dan seorang lagi tidak pasti sama ada wajar untuk berpuas hati atau tidak. Namun demikian, walaupun pekerja organisasi A menyatakan bahawa mereka berpuas hati, mereka juga menyatakan bahawa mereka terpaksa berpuas hati kerana mereka mempunyai kesukaran dalam mencari pekerjaan yang lain. Pekerja organisasi A juga ada menyatakan bahawa status kewarganegaraan mereka merupakan antara sebab mereka susah untuk mencari pekerjaan yang lain. Mereka bersyukur dengan kerja yang dilaksanakan walaupun terbeban dengan tugas yang diberikan oleh pihak majikan. Berikut antara pernyataan pekerja yang tidak berpuas hati dengan beban kerja dan jumlah gaji yang diterima.

"Saya tidak berpuas hati dengan beban tugas saya ini. Sengsara nak membersihkan blok ni..."

"Saya tidak berpuas hati sebab kerja sekarang tidak macam kerja dulu lagi, makin banyak kerja jika dibandingkan sebelum tahun 2013 (membandingkan dengan tugasan kerja sebelum pelaksanaan gaji minimum)...” 
Pernyataan tersebut di atas jelas menunjukkan bahawa ada kalangan pekerja yang tidak berpuas hati dengan beban kerja yang diberikan oleh majikan mereka di organisasi A. Namun demikian, terdapat responden yang berpuas hati pula memberikan alasan sukar mendapatkan pekerjaan lain dan terpaksa berpuas hati dengan beban kerja dan gaji yang diterima.

\footnotetext{
"Apa boleh buat. Saya terpaksa berpuas hati (dengan beban kerja dan gaji yang diterima) ...kerana bukan senang dapat kerja lain sekarang ... lebih-lebih lagi macam saya (merujuk kepada dirinya yang bukan warganegara Malaysia)...”
}

"Saya berpuas hati sebab susah mencari pekerjaan lain sekarang..." "Saya terpaksa berpuas hati dengan kerja saya walaupun gaji tidak memuaskan... gaji sikit tapi kerja banyak..."

Pernyataan tersebut menunjukkan bahawa ada responden yang terpaksa berpuas hati dengan kerja-kerja pembersihan yang ditugaskan kepada mereka walaupun gaji yang diberikan oleh majikan adalah kurang daripada gaji minimum. Dapatan turut menunjukkan bahawa status kewarganegaraan menjadi antara sebab mereka susah mencari pekerjaan yang lain. Keadaan ini seterusnya menunjukkan niat pusing ganti pekerja adalah rendah bagi organisasi A. Hal ini berlaku disebabkan hanya tiga daripada lapan orang pekerja yang mempunyai niat untuk berpindah tempat kerja disebabkan oleh beban kerja dan gaji yang kurang, namun lima orang lagi pekerja memilih untuk kekal bekerja di organisasi A.

Keadaan ini jauh sekali berbeza bagi organisasi B yang mana hampir kesemua pekerja berpuas hati dengan skop kerja yang diberikan dan hanya dua orang pekerja sahaja yang tidak berpuas hati dengan skop kerja dan gaji yang diterima. Walau bagaimanapun, kedua-dua orang pekerja yang tidak berpuas hati ini merupakan pekerja yang baru sahaja bekerja kurang daripada enam bulan dan disebabkan itulah mereka mendapat gaji kurang daripada RM800. Pernyataan kedua orang pekerja tersebut adalah seperti berikut.

"Saya tidak berpuas hati dengan gaji yang saya peroleh sebab semua rakan yang lain mendapat RM800 tapi saya dapat RM600 sahaja maksimum..."

(Mona, baru berkhidmat 4 bulan) 
"Buat masa ini, saya tidak berpuas hati dengan gaji yang diterima tetapi jika saya mendapat gaji RM800 mungkin baru berpuas hati..."

(Jannie, baru berkhidmat 4 bulan)

Apabila ditanya kepada pekerja mengenai niat pusing ganti kerja, hanya dua orang pekerja baru yang mempunyai niat untuk bertukar tempat kerja kerana khuatir pihak majikan tidak akan membayar gaji mereka seperti mana pekerja-pekerja yang lain di organisasi B. Ini dinyatakan oleh Mona: "Majikan saya mengatakan bahawa selepas enam bulan baru saya menerima RM800. Kalau dapat RM800 saya akan terus bekerja di sini tapi jika tidak, saya akan lari dari organisasi ini."

Perkara ini turut disokong oleh Jannie yang juga merupakan seorang pekerja baharu di organisasi B. Beliau menyatakan:

"Kalau saya dibayar RM800... saya tidak akan pindah tapi jika tidak, mungkin saya akan cari kerja lain."

Keadaan ini jelas menunjukkan bahawa terdapat responden,terutama yang baru bekerja di organisasi B masih ragu-ragu dengan pembayaran gaji minimum. Mereka berniat untuk berpindah jika tidak dibayar gaji seperti yang telah dijanjikan oleh majikan.

Namun demikian, kajian turut mendapati bahawa faktor usia juga memainkan peranan dalam isu pusing ganti pekerja ini. Ketiga-tiga pekerja yang berumur 50 tahun ke atas memilih untuk tidak bertukar tempat kerja kerana telah selesa bekerja dan mereka juga menyatakan bahawa faktor usia menyebabkan mereka memilih untuk setia bekerja dengan organisasi B kerana agak sukar untuk mencari pekerjaan yang lain pada usia melebihi 50 tahun. Hal ini dinyatakan oleh Limah seperti berikut:

"Saya tidak mahu pindah... sebab umur saya sudah lanjut... lagipun sekarang ni susah mendapat kerja."

Kenyataan tersebut turut disokong oleh Joyah yang sudah berusia 64 tahun tetapi masih setia bekerja di organisasi B. 


\begin{abstract}
"Saya tidak akan pindah kerja...usia saya sudah mencapai 64 tahun... bukan senang mahu cari kerja sekarang... kalau tinggal di rumah pun... bukan ada apa-apa yang boleh dibuat... lebih baik kerja... lagipun dekat dengan rumah..."
\end{abstract}

Mak Ita, salah seorang responden yang berusia melebihi 50 tahun turut mengakui perkara yang sama.

"Saya sudah tua. Jika ingin bertukar kerja akan menyusahkan kerana tidak ramai majikan ingin mengambil pekerja yang sudah berusia."

Pernyataan tersebut jelas menunjukkan bahawa faktor umur merupakan antara alasan sesetengah responden di organisasi B tidak berniat untuk berpindah atau bertukar pekerjaan.

\title{
KESIMPULAN
}

Kajian ini mendapati bahawa wujud unsur manipulasi maklumat dalam kalangan majikan atau pengurusan. Hal ini demikian kerana ada majikan yang telah mengekang pelaksanaan gaji minimum kepada pekerjanya namun beban pekerja ditingkatkan kerana kurang berkemampuan untuk menggaji pekerja. Pekerja juga seharusnya lebih peka dan berusaha memperoleh lebih banyak maklumat, khususnya tentang hak sebagai pekerja. Kajian ini telah menunjukkan bahawa rata-rata responden didapati tidak mempunyai maklumat mengenai gaji minimum dan tidak sedar mengenai hak mereka tentang pembayaran gaji. Hal ini telah menyumbang kepada manipulasi daripada pihak majikan mereka. Namun demikian, pihak pekerja juga didapati kurang mengambil peduli mengenai isu gaji minimum disebabkan oleh faktor kewarganegaraan pekerja kerana mereka memilih untuk bersyukur disebabkan mempunyai peluang bekerja walaupun tidak dibayar gaji minimum. Manipulasi terhadap pekerja tersebut menunjukkan perlunya pihak berkuasa memantau dan mengambil tindakan terhadap pelaksanaan gaji minimum, di samping dapat memastikan tiada majikan yang culas membayar gaji minimum kepada pekerja tanpa mengira warganegara dan pekerjaan. Di samping itu, MPGN khususnya haruslah melaksanakan pemantauan kepada kesemua sektor pekerjaan bagi menilai sejauh manakah 
pelaksanaan Akta Gaji Minimum dilaksanakan oleh pihak majikan tanpa perlu menunggu aduan pekerja yang tertindas. Hal ini demikian kerana MPGN merupakan pihak yang melaksanakan akta tersebut. Maka, telah menjadi tanggungjawab MPGN untuk melakukan pemantauan berkala di semua organisasi atau syarikat swasta.

Kajian ini pada dasarnya mempunyai limitasi kerana hanya terhad kepada dua syarikat pembersihan berskala kecil, justeru jika skop kajian ini perlu diperluaskan ke sektor dan industri yang berlainan dengan menggunakan pendekatan yang berbeza, sudah tentu ia akan menemukan dapatan yang juga berbeza.

\section{RUJUKAN}

Ambrosi, G. M. (1986). The Keynesian reception of classical analysis: Pigou's Theory of unemployment and it s' critique in keynes' general theory. https:// www.uni-trier.de/fileadmin/fb4/prof/VWL/EWP/Publikationen/Ambrosi/ keypigo.pdf. Diakses pada 7 April 2014.

Davies, A. (2013). Unintended consequences of raising the minimum wage. http:// mercatus.org/sites/default/files/unintended-consequences-raising-minimumwage.pdf. Diakses pada 7 April 2014.

Dieleman, Marjolein \& Harnmeijer, Jan Willem. (2006). Improving health worker performance: In search of promising practises. http://www.who.int/hrh/ resources/improving_hw_performance.pdf. Diakses pada 20 April 2014.

Ezzeddine, Oussama. (2011). The role of labour mobility in reducing unemployment in the European Union. http://www.euroframe.org/file/user_upload/ euroframe/docs/2011/EUROF11_Ezzeddine.pdf. Diakses pada 20 Jun 2014.

Heinz, Frigyes Ferdinand \& Ward-Warmedinger, Melanie. (2006). Cross-border labour mobility within an enlarged EU. http://ecb.europa.eu/pub/pdf/scpops/ ecbocp52.pdf. Diakses pada 20 April 2014.

International Labour Office. (2014). Minimum wage systems. http://www.ilo.org/ wcmsp5/groups/public/---ed_norm/--relconf/documents/meetingdocument/ wcms_235287.pdf. Diakses pada 17 Jun 2014.

Kementerian Sumber Malaysia, Putrajaya. (2012). Gaji minimum sektor swasta: Penjelasan mengenai perbezaan antara Sabah, Sarawak dan Labuan dengan Semenanjung. http://www.mohr.gov.my/pdf/umum_gaji_minimum_ss.pdf. Diakses pada 20 September 2013. 
Kementerian Sumber Manusia. (2015). Mengenai dasar gaji minimum Malaysia: Latar belakang dasar gaji minimum di Malaysia. http://minimumwages. mohr.gov.my/pekerja/mengenai-dasar-gaji-minimum-malaysia/?lang=my masa. Diakses pada 15 Januari 2015.

Kenyataan Akhbar YB Datuk Richard Riot Anak Jem Menteri Sumber Manusia.http:/www.mohr.gov.my/docz/KENYATAAN_AKHBAR_CA_ GENTING26913.pdf. Diakses pada 23 April 2014.

Lee Heng Guie. (2012). Minimum wage policy - Curse or cure?, Malaysia CIMB Economic Update. http://etp.pemandu.gov.my/upload/CIMB-Minimum wage_policy\%E2\%80\%93Curse_or_Cure.pdf. Diakses pada 20 Mac 2014.

Lilly Ledbetter Fair Pay Act. (2009). One hundred eleventh congress of the United States of America. http://www.gpo.gov/fdsys/pkg/BILLS-111s181enr/pdf/ BILLS-111s181enr.pdf. Diakses pada 24 April 2014.

Majlis Perundingan Gaji Negara. (2011). Undang-Undang Malaysia Akta 732. http://www.federalgazette.agc.gov.my/outputaktap/20110915_AKTA\%20 732 BM_Akta\%20732\%20BM.pdf. Diakses pada 23 Jun 2015.

Majlis Perundingan Gaji Negara. (2012). Kementerian Sumber Manusia. Soalan Lazim (FAQ) berkaitan gaji minimum di Malaysia. http://www.mohr.gov. my/pdf/FAQ_GAJIMINIMUM.pdf. Diakses pada 20 September 2013.

Neumark, D. \& Wascher, W. (2007). Minimum wages the earned income tax credit and employment: Evidence from the post-welfare reform era. http://ftp.iza. org/dp2610.pdf. Diakses pada 23 April 2014.

Perintah Gaji Minimum (2013). Warta Kerajaan Persekutuan: P.U. (A) 214. http:// www.mohr.gov.my/docz/perintahgajiminimum2013.pdf. Diakses pada 20 September 2013.

Scotland Equal Opportunities Commision. (2003). Equal pay, fair pay. http://www. closethegap.org.uk/content/resources/Equal-Pay-Fair-Pay.pdf. Diakses pada 20 Mac 2014.

Supreme Court of the United States. (2007). Lilly M. Ledbetter, Petitioner V. The Good-Year Tire \& Rubber Company, Inc. http://www.supremecourt.gov/ opinions/06pdf/05-1074.pdf. Diakses pada 24 Jun 2014.

Thurab-Nkhosi, D. (2007). Bridging the gap between policy and implementation: Moving from singlet o dual mode at the university of the West Indies. http:// mjde.usm.my/vo19_2_2007/mjde9_2_2.pdf. Diakses pada 17 Jun 2014.

Tiada Lagi Rayuan Tunda Gaji Minimum - Richard Riot. http://www.utusan.com. my/utusan/Dalam_Negeri/20130701/dn_37/Tiada-lagi-rayuan-tunda-gajiminimum---Richard-Riot. Diakses pada 24 April 2014. 
